\title{
KARYA PUISI PURNOMO
}

\section{Siti Mahmudah}

Universitas Nahdlatul Ulama Sidoarjo

\section{LATAR BELAKANG}

Puisi adalah sastra pada ayat-ayat yang bertentangan dengan teks pada prosa. Puisi juga dapat digunakan untuk sesuatu yang membangkitkan perasaan dan suasana hati (Hamm, 2019).

Apa itu puisi, baik "dalam dirinya sendiri" maupun dalam hubungannya dengan prosa, ada banyak upaya untuk menggambarkan. Setiap upaya untuk mendefinisikan puisi sekali dan untuk semua pada tingkat umum harus dikatakan agak tidak berhasil, setidaknya dalam arti bahwa akan selalu ada pengecualian untuk aturan tersebut. Ini sebagian disebabkan oleh kenyataan bahwa dalam sifat puisi untuk berusaha memperbarui, menjadi sesuatu yang lain. Setiap 
puisi yang baik dapat dikatakan untuk menciptakan kembali genre. Di sisi lain, ketika para penyair berusaha menggambarkan dasar dari puisi mereka sendiri , ia memiliki lebih banyak peluang untuk berhasil. Ketika seorang penyair berusaha menjawab satu atau lebih pertanyaan: apa, bagaimana dan mengapa sehubungan dengan puisinya sendiri, kita mengatakan bahwa penyair merumuskan sebuah puisi. Jika kita kembali ke makna asli kata-kata itu, etimologinya, puisi berarti "puisi disertai permainan derek", sedangkan kata puisi berasal dari poiesis yang berarti menciptakan. Oleh karena itu, pada zaman kuno, "puisi" tidak hanya merujuk pada puisi, tetapi juga puisi epik dan dramatis. Saat ini, istilah "puisi" dan "puisi" sering digunakan secara bergantian. Penulis telah memilih untuk tetap berpegang pada istilah puisi di halaman-halaman ini, karena itu mencakup semua tulisan yang dapat disebut "puitis", apakah itu puisi modern dengan margin yang tidak rata, ayat-ayat tentang sajak, puisi lagu, puisi visual, rap dan kata yang 
diucapkan , atau ekspresi linguistik lain yang memiliki sikap "puitis" terhadap dunia dan dirinya sendiri (Strøm, 2016).

Untuk menentukan apa peran puisi dalam masyarakat, pertama-tama kita perlu membangun definisi yang berfungsi tentang apa itu puisi yaitu tulisan yang merumuskan kesadaran imajinatif terkonsentrasi dari pengalaman dalam bahasa yang dipilih dan diatur untuk menciptakan respons emosional tertentu melalui makna, suara, dan ritme. Puisi berperan menyampaikan kesadaran pengalaman yang memperkuat perannya dalam masyarakat pada umumnya. Yaitu pada menyampaikan pengalaman dengan cara yang sangat menonjol, ada potensi besar untuk dimanfaatkan sebagai sarana untuk membangun empati dan menjembatani kesenjangan pemahaman antara orang-orang yang datang dari latar belakang yang berbeda. Dengan cara ini puisi bisa menjadi wahana pesan keadilan sosial (Kemp, 2017). 


\section{Tabel 1. Daftar Puisi Agung Purnomo}

\begin{tabular}{|c|c|c|c|c|c|c|}
\hline No & $\begin{array}{l}\text { Judul } \\
\text { buku }\end{array}$ & Penulis & $\begin{array}{l}\text { Judul } \\
\text { Puisi }\end{array}$ & $\begin{array}{l}\text { Jenis } \\
\text { puisi }\end{array}$ & Penerbit & Tahun \\
\hline 1 & $\begin{array}{r}\text { Bhumi } \\
\text { Bawera }\end{array}$ & $\begin{array}{r}\text { Agung } \\
\text { Purnomo, } \\
\text { Nur } \\
\text { Asitah }\end{array}$ & Tangisnya & $\begin{array}{r}\text { Puisi } \\
\text { Naratif }\end{array}$ & $\begin{array}{r}\text { STIEBA } \\
\text { Madura } \\
\text { Press }\end{array}$ & 2019 \\
\hline 2 & $\begin{array}{r}\text { Tolesan } \\
\text { Aditi }\end{array}$ & $\begin{array}{r}\text { Agung } \\
\text { Purnomo, } \\
\text { Nur } \\
\text { Asitah }\end{array}$ & Pandai & $\begin{array}{r}\text { Puisi } \\
\text { Riddle }\end{array}$ & $\begin{array}{r}\text { STIEBA } \\
\text { Madura } \\
\text { Press }\end{array}$ & 2019 \\
\hline 3 & $\begin{array}{r}\text { Syair } \\
\text { Nimala } \\
\end{array}$ & $\begin{array}{r}\text { Agung } \\
\text { Purnomo } \\
\end{array}$ & Berpulang & $\begin{array}{r}\text { Puisi } \\
\text { epitaf }\end{array}$ & $\begin{array}{r}\text { STIEBA } \\
\text { Madura } \\
\text { Press }\end{array}$ & 2019 \\
\hline 4 & $\begin{array}{l}\text { Kidung } \\
\text { Nawala } \\
\text { (Jilid 2) }\end{array}$ & $\begin{array}{r}\text { Agung } \\
\text { Purnomo }\end{array}$ & Dua Kaki & $\begin{array}{r}\text { Puisi } \\
\text { Bebas }\end{array}$ & $\begin{array}{r}\text { UNUSIDA } \\
\text { Press }\end{array}$ & 2018 \\
\hline 5 & $\begin{array}{r}\text { Arebhan } \\
\text { Helai }\end{array}$ & $\begin{array}{r}\text { Agung } \\
\text { Purnomo, } \\
\text { Nur } \\
\text { Asitah }\end{array}$ & $\begin{array}{r}\text { Sepekan } \\
\text { Awal } \\
\text { Tanpamu }\end{array}$ & $\begin{array}{r}\text { Puisi } \\
\text { bersekuen }\end{array}$ & $\begin{array}{r}\text { STIEBA } \\
\text { Madura } \\
\text { Press }\end{array}$ & 2019 \\
\hline 6 & $\begin{array}{r}\text { Lembhar } \\
\text { Jiwana }\end{array}$ & $\begin{array}{r}\text { Agung } \\
\text { Purnomo, } \\
\text { Nur } \\
\text { Asitah }\end{array}$ & Cantik & $\begin{array}{r}\text { Puisi } \\
\text { Jenaka } \\
\text { Limerick }\end{array}$ & $\begin{array}{r}\text { STIEBA } \\
\text { Madura } \\
\text { Press }\end{array}$ & 2019 \\
\hline 7 & $\begin{array}{r}\text { Kidung } \\
\text { Nawala } \\
\text { (Jilid 1) }\end{array}$ & $\begin{array}{r}\text { Agung } \\
\text { Purnomo }\end{array}$ & $\# \mathrm{CH} 1$ & $\begin{array}{r}\text { Puisi } \\
\text { Bebas }\end{array}$ & $\begin{array}{r}\text { UNUSIDA } \\
\text { Press }\end{array}$ & 2018 \\
\hline 8 & $\begin{array}{r}\text { Tenta } \\
\text { Kimaya }\end{array}$ & $\begin{array}{r}\text { Agung } \\
\text { Purnomo }\end{array}$ & Menyala & $\begin{array}{r}\text { Puisi } \\
\text { Haiku }\end{array}$ & $\begin{array}{r}\text { STIEBA } \\
\text { Madura } \\
\text { Press }\end{array}$ & 2019 \\
\hline 9 & $\begin{array}{r}\text { Rassana } \\
\text { Jlantir }\end{array}$ & $\begin{array}{r}\text { Agung } \\
\text { Purnomo }\end{array}$ & $\begin{array}{r}\text { Rindu di } \\
\text { Ubun- } \\
\text { Ubun }\end{array}$ & $\begin{array}{r}\text { Puisi } \\
\text { Bebas }\end{array}$ & $\begin{array}{r}\text { STIEBA } \\
\text { Madura } \\
\text { Press }\end{array}$ & 2019 \\
\hline 10 & $\begin{array}{r}\text { Suweda } \\
\text { Ate }\end{array}$ & $\begin{array}{r}\text { Agung } \\
\text { Purnomo, } \\
\text { Elsa } \\
\text { Rosyidah }\end{array}$ & Kita & $\begin{array}{r}\text { Puisi } \\
\text { Bebas }\end{array}$ & $\begin{array}{r}\text { STIEBA } \\
\text { Madura } \\
\text { Press }\end{array}$ & 2019 \\
\hline 11 & $\begin{array}{r}\text { Dhalubang } \\
\text { Marta }\end{array}$ & $\begin{array}{r}\text { Agung } \\
\text { Purnomo, } \\
\text { Nur } \\
\text { Asitah }\end{array}$ & $\begin{array}{r}\text { Bapak } \\
\text { Samsuri }\end{array}$ & $\begin{array}{r}\text { Puisi } \\
\text { Clerihew }\end{array}$ & $\begin{array}{r}\text { STIEBA } \\
\text { Madura } \\
\text { Press }\end{array}$ & 2019 \\
\hline
\end{tabular}




\section{ULASAN KARYA}

Penikmat seni dapat membaca puisi gubahan Agung Purnomo dalam tajuk: tangisnya (Purnomo \& Asitah, 2019e), pandai (Purnomo \& Asitah, 2019c), dan kita (Purnomo \& Rosyidah, 2019), rindu di ubun-ubun (Purnomo, 2019c), sepekan awal tanpamu (Purnomo \& Asitah, 2019d), \#CH1 (Purnomo, 2018a), cantik (Purnomo \& Asitah, 2019b), berpulang (Purnomo, 2019a), dua kaki (Purnomo, 2018b), bapak Samsuri (Purnomo \& Asitah, 2019a), dan menyala (Purnomo, 2019b).

Purnomo telah menulis sebelas puisi dengan gaya bebas, epitaf, clerihew, riddle, bersekuen, haiku, dan jenaka limerik. Puisi diterbikan pada periode tahun 2018 dan tahun 2019. Puisinya kadang menarik, namun juga kadang membosankan. Anda bisa membacanya. 


\section{PENYAIR}

Penyair lahir dengan nama lengkap Agung Purnomo dan tumbuh di Sidoarjo. Tulisan puisi beliau telah disebarkan secara luas melalui penerbit nasional, yaitu: STIEBA Madura Press, dan UNUSIDA Press.

\section{REFERENCES}

Hamm, C. (2019). Poesi. Retrieved June 22, 2019, from https://snl.no/poesi

Kemp, M. (2017). Defining the Role of Poetry in Society: The Ongoing Conversation. Retrieved June 29, 2019, from https://arts.cgu.edu/tuftspoetry-awards/defining-role-poetry-societyongoing-conversation/

Purnomo, A. (2018a). \#CH1. In Kidung Nawala (Jilid 1). Sidoarjo: UNUSIDA Press.

Purnomo, A. (2018b). Dua Kaki. In Kidung Nawala (Jilid 2). Sidoarjo: UNUSIDA Press.

Purnomo, A. (2019a). Berpulang. In Syair Nimala. Sumenep: STIEBA Madura Press.

Purnomo, A. (2019b). Menyala. In Tenta Kimaya. Sumenep: STIEBA Madura Press.

Purnomo, A. (2019c). Rindu di Ubun-Ubun. In Rassana Jlantir. Sumenep: STIEBA Madura Press. 
Purnomo, A., \& Asitah, N. (2019a). Bapak Samsuri.

In Dhalubang Marta. Sumenep: STIEBA Madura Press.

Purnomo, A., \& Asitah, N. (2019b). Cantik. In

Lembhar Jiwana. Sumenep: STIEBA Madura Press.

Purnomo, A., \& Asitah, N. (2019c). Pandai. In

Tolesan Aditi. Sumenep: STIEBA Madura Press.

Purnomo, A., \& Asitah, N. (2019d). Sepekan Awal

Tanpamu. In Arebhan Helai. Sumenep: STIEBA Madura Press.

Purnomo, A., \& Asitah, N. (2019e). Tangisnya. In

Bhumi Bawera. Sumenep: STIEBA Madura

Press.

Purnomo, A., \& Rosyidah, E. (2019). Kita. In Suweda Ate. Sumenep: STIEBA Madura Press.

Strøm, C. (2016). Hva er Poesi ?. Retrieved June 27, 2019, from

https://bergenbibliotek.no/litteraturen/poesi/litter atur-poesi 